\title{
Water Supply System for a Rural Village in Malaysia
}

\author{
Prashobh Karunakaran*, M. Shahril Osman, Lawrence M Nyomui, Clement Langet Sabang, Prashanth Karunakaran, Shanthi Karunakaran, \\ Arjun Karunakaran, Dylan Greve, Timothy Jesse, Abd. Hakim \\ University College of Technology Sarawak (UCTS), \\ Sarawak, Malaysia \\ *prashobh.karunakaran@gmail.com
}

\begin{abstract}
The aim of this research was to design and build a water supply system for a village in rural Malaysia. Very often technologies previously developed for water supply are not known or specifically upgraded to suit a particular population (or village). This has resulted in 600 million humans still living in abject poverty. Companies can be called in to develop water supply systems but too often their profit motive will make the project inviably expensive. This project was accomplished with a very tight research grant, lots of trial and error and engineering knowledge. The village is located 103 kilometers from Kuching. The final system is a $3 \emptyset, 4 \mathrm{HP}$ pump placed on a floatable wooden barge near the river pushing water up $120 \mathrm{~m}$ over an elevation of 9m to a Pump House located behind the Community Hall of the village. Another 3Ø, $1 \mathrm{HP}$ pump is used to pump water from the 9000L holding tank to the 38 individual homes of the village. Upon achieving a supply of water, other aspects of developing the village using modern technology was worked upon. This will enable villagers to get out of the poverty trap and approach life with renewed confidence.
\end{abstract}

Index Terms- water supply system, electric pump, Kuching, Autotran starter, HDPE, techno-economic, poverty trap

\section{INTRODUCTION}

The rural areas of Sarawak, Malaysia has been lagging in terms of socio-economic development [1]. Among the reasons for this is that development initiatives have not had the value for the money spent. Also, development budgets are dispersed over a wide area making them thin [2]. This has caused the outreach of development initiatives through government programs not reaching the rural people appropriately [3]. It is because of this problem that it is justifiable to look for some means to complement the efforts of the government. One of the ways is to harness the knowledge and expertise of university's professionals into the rural development fray. This can be done through small projects sponsored through the research grants of the universities.

This paper describes the design and building of a water supply system for a village named Kampung Abit in the Sri Aman Division of Sarawak, Malaysia. The village is located just off the Pan Borneo Highway, about $103 \mathrm{~km}$ from Kuching city. There are 38 individual homes and not jointed longhouses which are common among the Iban communities who live

This work was supported by the University Research Grant, of University College of Technology Sarawak (UCTS), Sarawak, Malaysia under grant reference no.: UCTS/Research/<4/2017/14>(01).

Prashobh Karunakaran is a senior lecturer in Electrical Engineering at University College of Technology Sarawak (UCTS), Sarawak, Malaysia (email: prashobh.karunakaran@gmail.com). around this area. Prior to implementing this project, the village had no water supply and villagers had to walk up to one $\mathrm{km}$ and down $9 \mathrm{~m}$ to get a bucket of water. The last 20 feet near the river bank is a $60^{\circ}$ slippery slope. This slippery slope is a particular deterrent for villagers getting buckets of water from the river. Most homes in this village have a big plastic container to tap rain water pouring down from their roof gutters and there is a larger tank taping water flowing down from the roof of the Community Hall. But during the dry season months of June, July and August there is a dearth of water supply. Thereby this project has vastly improved the quality of life in this village. The villagers cannot even confidently grow vegetables because a sudden lack of water can kill all the vegetables in their farms, especially during the dry season [4]. For some reason this village is particularly dry, compared even to regions $20 \mathrm{~km}$ before it, as one drives to it from Kuching.

Once the water supply system was finished the economic upliftment of the people of the village was looked into. The means of economic upliftment are: 1) Introducing best farming practices for vegetables, 2) Setting up a metal foundry to enable the villagers to create metal tools starting with long knives which are an absolute necessity for walking in equatorial jungles, 3) A smokeless wood burning stove to replace the gas burning stove. A tank of gas costs $\$ 8$ which is quite high for the villagers to purchase every month while wood is inexhaustible in an equatorial forest, 4) A Homestay business because richer parents of Kuching city will like to get their children away from their phones and other electronic devices. This will build quality among Kuching city youths as well as much needed income for the villagers.

\section{LITERATURE REVIEW}

Water is a basic necessity for human life as well as for all life in general. Rural water supply has typically been overshadowed by the needs of cities. Water is used in rural areas for life as well as to enhance food production and therefore income [5]. In Sarawak, rivers have historically been critical to enable villagers to transport produce from the village or the jungles around them and to purchase factory produced products. often via barter trade [6].

During the initial stages after Malaysia's independence in 1957 and Sarawak's joining Malaysia in 1963, there was little progress in rural Malaysia. Persistence of chronic poverty, low productivity, lack of access to basic infrastructure, poor health and education were common problems faced by the rural communities [7].

Over the years the government has initiated various policies and programs towards the development of rural areas. This is done in the interest of addressing the problems of 
underdevelopment of the infrastructural facilities in the rural areas and at the same time to uplift the standard of living of the rural people. The timeline and the various policies and programs initiated by the government for the purpose of rural development in Malaysia is set out in Table 1 [8].

One outstanding achievement resulting from these initiatives has been the reduction of poverty rates from $49 \%$ in 1970 to $1.3 \%$ in 2020 . However, the poverty level in rural areas remains higher than urban areas; notably in some northern states of Peninsular Malaysia, and in the two largest states of Sabah and Sarawak in East Malaysia [7,8,9].

TABLE I. RURAL DEVELOPMENT IN MALAySIA

\begin{tabular}{|c|c|c|c|}
\hline Period & Context & Economic Plan & Rural Development Strategies \& Program \\
\hline 2020 & \begin{tabular}{|l|} 
New Economic Model (OPP4) \\
High income, inclusiveness and \\
sustainability
\end{tabular} & $\begin{array}{l}11^{\text {th }} \text { Malaysia Plan } \\
10^{\text {th }} \text { Malaysia Plan }\end{array}$ & $\begin{array}{l}\text { Rural Economic Transformation (NKRAS). } \\
\text { Improve quality of life. } \\
\text { Entrepreneurship \& SMI. } \\
\text { Rural Transformation Centre. }\end{array}$ \\
\hline \multirow[t]{2}{*}{2010} & \multirow[t]{2}{*}{$\begin{array}{l}\text { National Vision Policy (OPP3) } \\
\text { Building a resilient and } \\
\text { competitive nation }\end{array}$} & $9^{\text {th }}$ Malaysia Plan & \multirow{2}{*}{$\begin{array}{c}\text { Gerakan Daya Wasasan. } \\
\text { Improve quality of life. } \\
\text { Expand infrastructure \& amenities to remote } \\
\text { areas. } \\
\text { Zero hardcore poverty. }\end{array}$} \\
\hline & & $8^{\text {th }}$ Malaysia Plan & \\
\hline \multirow[t]{2}{*}{2000} & \multirow[t]{2}{*}{$\begin{array}{l}\text { New Development Policy } \\
\text { (OPP2) } \\
\text { Growth with equity }\end{array}$} & $7^{\text {th }}$ Malaysia Plan & \multirow{2}{*}{$\begin{array}{c}\text { New philosophy \& strategy of Rural } \\
\text { Development. } \\
\text { (A developed, attractive \& profitable rural). } \\
\text { Gerakan Desa Wawasan. } \\
\text { Eradicate hardcore poverty. }\end{array}$} \\
\hline & & $6^{\text {th }}$ Malaysia Plan & \\
\hline \multirow{2}{*}{1990} & \multirow{2}{*}{$\begin{array}{l}\text { New Development Policy } \\
\text { (OPP2) } \\
\text { Growth with equity }\end{array}$} & $5^{\text {th }}$ Malaysia Plan & \multirow{2}{*}{$\begin{array}{l}\text { New approach to Village \& Rural Development } \\
\text { Rural Growth Centre. }\end{array}$} \\
\hline & & $4^{\text {th }}$ Malaysia Plan & \\
\hline \multirow[t]{2}{*}{1980} & \multirow[t]{2}{*}{\begin{tabular}{|l|} 
New Economic Policy (OPPl) \\
Eradication of poverty and \\
restructuring of society
\end{tabular}} & $3^{\text {rd }}$ Malaysia Plan & \multirow{2}{*}{$\begin{array}{l}\text { New land development schemes. } \\
\text { Regional development. } \\
\text { Integrated in-situ development. } \\
\text { Orang Assi Regrouping Schemes. }\end{array}$} \\
\hline & & $2^{\text {nd }}$ Malaysia Plan & \\
\hline \multirow[t]{2}{*}{1970} & \multirow[t]{2}{*}{$\begin{array}{l}\text { Economic Growth (Laissez- } \\
\text { faire approach) }\end{array}$} & $1^{\text {st }}$ Malaysia Plan & \multirow{2}{*}{$\begin{array}{l}\text { Basic infrastructure \& social facilities. } \\
\text { Modernisation \& diversification of crops. } \\
\text { New land schemes. } \\
\text { Community Development. } \\
\text { Red Book. } \\
\end{array}$} \\
\hline & & $2^{\text {nd }} \mathrm{SYP}$ & \\
\hline 1960 & $\begin{array}{l}\text { Colonial policy of resource } \\
\text { exploitation }\end{array}$ & $1^{\text {st }}$ SYP & $\begin{array}{l}\text { New Village Schemes. } \\
\text { Infrastructure for resource exploitation. }\end{array}$ \\
\hline
\end{tabular}

With regards to piped water, the percentage of piped water in rural areas of Peninsular Malaysia increased from $42 \%$ to $96 \%$ in 2020 [9]. However, Sabah and Sarawak lagged behind with only $62 \%$ in 2020 . Among the factors that contribute to the lower coverage of piped water in Sabah and Sarawak are due to the $[10,11]$ :

- Undulating topography that makes the cost of providing infrastructure very expensive

- Vastness of the rural areas spreads out the rural development efforts thinly over wide expanse that it becomes less noticeable

- Sparse and scattered rural population in the two states makes it uneconomical to lay out water pipes across vast areas to reach remote and scattered villages.

To compound the problem, there seems to be no coordinated efforts on the part of both the state and federal governments to integrate their development programs in a holistic manner. Rural transformation development in Malaysia appears to be fragmented, project oriented and lacks integration on the overall transformation development. For example, there appears to be a lack of coordination and relationship between the various rural transformation programs such as ETP (economic transformation program), RTC (rural transformation center) and NKRA (a Malay abbreviation meaning national key outcomes). The implication is that for rural change in Malaysia to succeed the various dimensions of rural changes, rural diversities, and the increasing differentiated rural spaces need to be looked into $[12,13]$.

To overcome the structural problems mentioned above and at the same time to fill the gap in the government's fragmented development efforts, this research project hopes to reach out to those rural communities which have been left out in the development efforts. This is where the considerations for the "various dimensions, diversities, and differentiated rural spaces" comes into play [13].

\section{Methodology}

To solve the hardships caused by water scarcity of the village an electric system was built to draw water from a river located away from the center of the village by $120 \mathrm{~m}$ horizontally and $9 \mathrm{~m}$ vertically. A long process of much trial and error was gone through to finally achieve success.

Since the village is $103 \mathrm{~km}$ from Kuching city, the initial testing was done in a technical school owned by this author. It is hard to do research in the village where even if a small screw is missing, a four-hours (to and fro, two hours each) journey needs to be made to acquire it. But at the village it was discovered that the pump must be near the river, which is why often submersible pumps are utilized by industry to draw water over a vertical distance [14]. For this village however a submersible pump was decided to be not the optimum solution from the onset because placing an electrical device in water, especially a high powered one will be prone to failures. The problems include the submersible pump being very dirty and workers will be reluctant to service it. And if vendors are called, they will charge a premium price for maintaining it. Leaks will develop over time causing short circuits. The implication of a short circuit is especially aggravated if the protection system does not function due to the encroachment of fauna into them. In a previous repair work of a goat farm located in a rural area by this author, it was noticed that electrical equipment gets damaged fast in rural Sarawak because the equatorial climate is teeming with a rich variety of fauna species like insects and lizards. It was observed that there was a dead lizard in every single live point [14]. In another repair of a rural school a tiny insect made the whole DB (distribution board) of a rural school their home; in this case many protective devices had to be replaced. The heat of the protective switches must have attracted them to the DB. In rural areas, there is a lack of electrical knowledge and for the school case; nobody entered the DB room for ages [14]. An aluminum netting surrounding the electrical devices is critical. It must be noted that the typical home netting which is made of silicone is not appropriate because lizards can chew through them [14]. In this project it was decided that the autotran circuit is placed in a metal cabinet. Another metal cabinet houses the DB and one more to house the incoming cut-out fuse, neutral link and power measuring meter. All holes of the motor must 
also be totally sealed. In Western countries these tiny creatures will disappear during the winter and have to start procreation again during the warmer seasons. But in equatorial countries, they keep growing all throughout the year [14].

The river in this village is located at one low elevation corner of the village as shown in Fig. 1. Up about 20' from the river is the first flat land which was the original designed location of the 9000L holding tank and pump. This small flat portion is just enough for three homes. Then the land slopes uphill for another 10' vertically to locate the rest of the homes in the village.

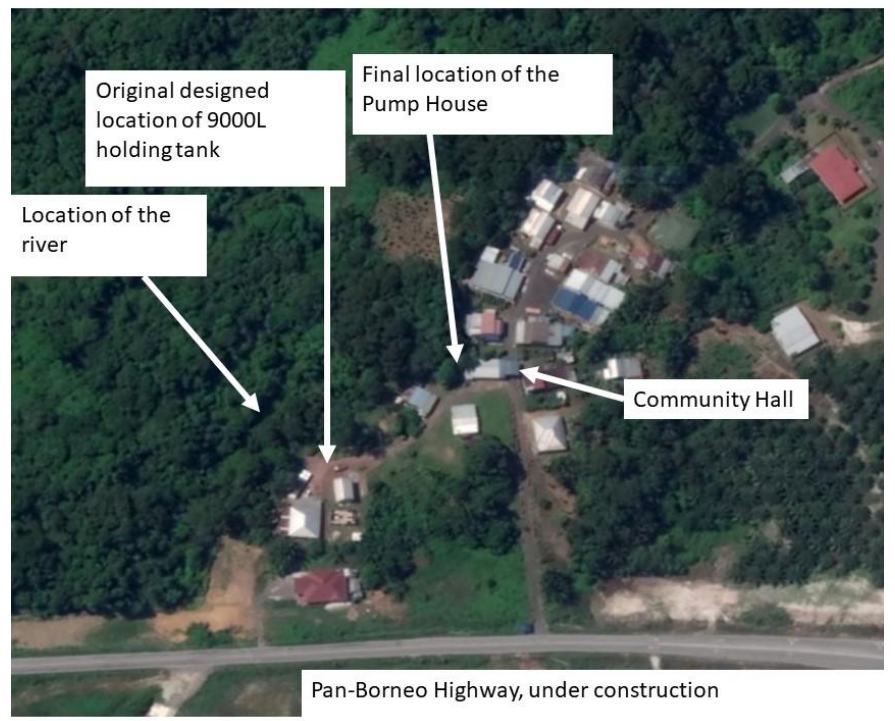

Fig. 1. Location of the river with respect to the Pump House

So, the initial design developed was to locate the 9000L HDPE holding tank and $1 \mathrm{HP}$ centrifugal pump in this first flat portion just up the river. An assumption initially made that the water pressure at the bottom of the $9000 \mathrm{~L}$ tank will be sufficient to push up the water a further 10' to the flat land where all the rest of the homes are located. To prove this hypothesis, an experiment was done. A 20' electrical conduit was sunk at the diving portion of an Olympic type swimming pool. The standard electrical conduit is 12' and two were joined and 4' was cut off to get a $20^{\prime}$ conduit. The hypothesis was that the water pressure at the bottom of the swimming pool (which will hurt any human's ear drums) will push water up the conduit. But the result was negative as shown in Fig. 2; no water gushed out. This result therefore disproved the hypothesis that water will go up another $10^{\prime}$ to the rest of the village via the high pressure at the bottom of the 9000L holding tank [15].

The initial parts purchased were the 9000L HDPE (high density polyethylene) tank and a $1 \mathrm{HP}$ centrifugal pump. Both were initially brought to the village as a guarantee to the villagers that this project is a confirmed thing.

The design was then changed to locate the 9000L HDPE tank behind the Community Hall which is located in the flat portion of land where most of the other homes of the village is located. This was agreed by the village leadership. But since this is further vertically and horizontally from the river, a $4 \mathrm{HP}$ pump was purchased. The originally bought $1 \mathrm{HP}$ pump will be utilized to push water from the holding tank to the village homes [15].

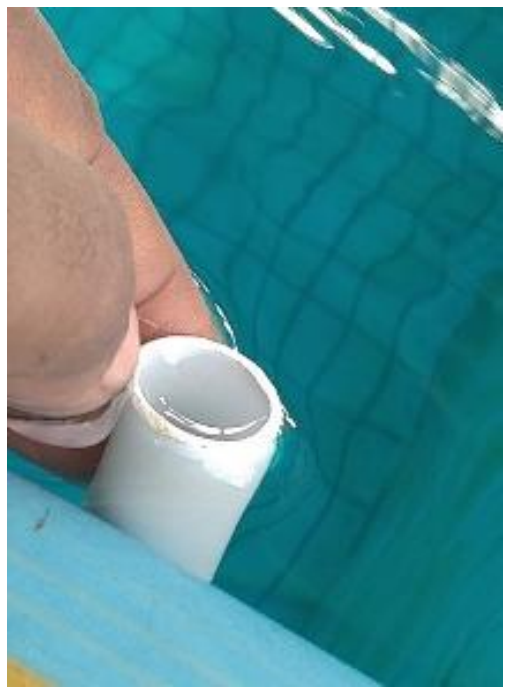

Fig. 2. A 20 ' electrical conduit in a swimming pool

The villagers were informed to build a strong floor because the 9000L tank will carry 9 tons of water. BRC and cement, sand and gravel were purchased for the villagers to build the strong floor. These construction materials are shown in Fig. 3 left. BRC means a wire mesh of welded steel for reinforcement of concrete structures. The abbreviation BRC originally represented the British Reinforcement Company of Britain. The final strong floor built is shown in Fig. 3 right.
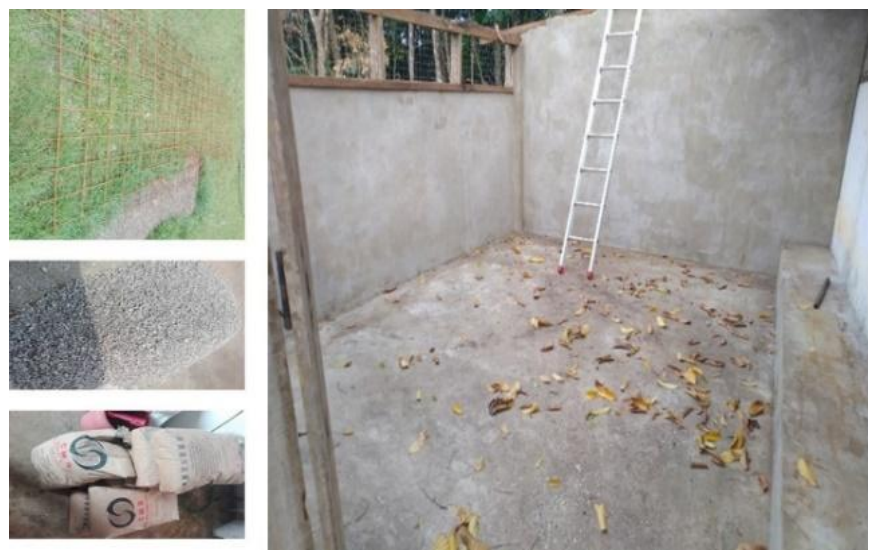

Fig. 3. The BRC, gravel, cement and sand and the reinforced floor to place the $9000 \mathrm{~L}$ holding tank

The 9000L HDPE tank was then moved onto the strong floor with great difficulty because it is very heavy. The next big problem was to determine how to stop the pump once the tank is full. Various vendors were contacted. Some vendors quoted with figures like \$1750. Finally, a co-researcher suggested trying a local shop near the university and the pressure sensor was purchased as shown in Fig. 4 right-top for only \$20 [15]. This sensor works with the float sensor shown in Fig. 4 rightbottom. Then the rest of the system was built at a school in Kuching (owned by this author) as depicted in Fig. 4 left. Two large garbage tanks were purchased to represent the river and the 9000L holding tank as shown in Fig. 4 left. The 1/1/2" HDPE 
pipe is totally not flexible and not possible to be cut with a standard pipe cutter. The plastic is too hard. So, an electric grinder was used to cut it. This spilled lots of plastic dust all over the place and the burrs created at the cut portion (Fig. 4 middle-bottom) was another problem. Due to the burrs the $1 \frac{1}{2}$ ", HDPE pipe will not go into the elbows easily. All the burrs have to be cut off diligently. Later one of the students in the school introduced a better cutter depicted in Fig. 4 middle top. It provided a perfect cut as shown in Fig. 4 middle, second picture down [15].
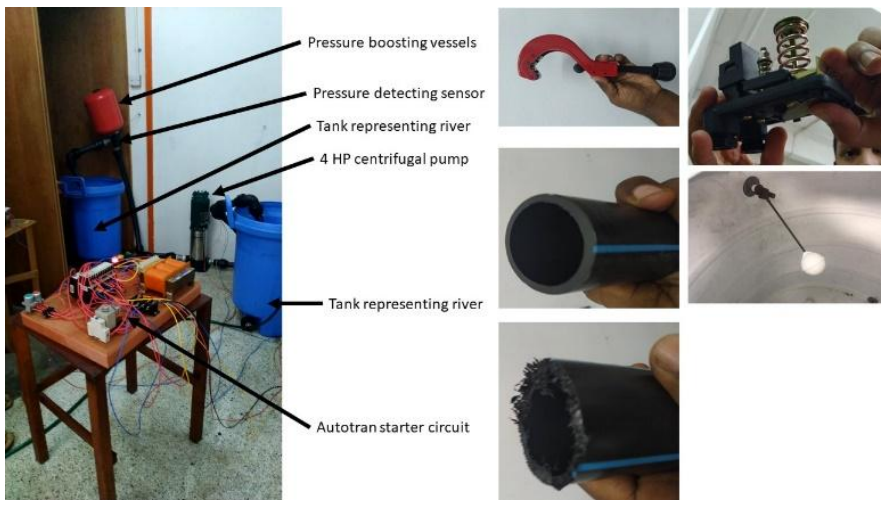

Fig. 4. Designing, building and testing the system in the school

Initially the autotran starter circuit was designed and built. It must be noted that an autotran starter circuit is needed because the rotors of the induction motor of the pump have an inertia and to initially overcome the inertia extra current is needed. Therefore, the voltage of each of the three motor coils are initially reduced with the autotran circuit to $70 \%$ of the incoming voltage or $168 \mathrm{~V}$ for a period of $6 \mathrm{~s}$ prior to providing the full 240V [16].

$$
\frac{70}{100} \times 100=168 \mathrm{~V}
$$

If this is not taken care of, there will be mechanical stress at the two bearings holding each ends of the rotor shaft. Also, the inertia of the rotor will cause it to draw extra current which could be above the current carrying capacity of the motor coil wire thereby damaging them. In other words, mechanical stress and electrical stress is the reason for utilizing motor starters. The 4 HP pump motor terminal is connected in the Star (Y) format as recommended by the vendor. This means there are three $\varnothing$ wires going to three terminals and the bottom (or vice versa) three terminals are looped with copper bars as shown in Fig. 5. This is why the voltages are as listed in the last few sentences. The voltages look like single $\varnothing$ but it is actually three $\varnothing$ since each of the three motor coils will receive $168 \mathrm{~V}$ and then $240 \mathrm{~V}$ as opposed to the whole motor receiving $240 \mathrm{~V}$ in a single $\varnothing$ motor [16].

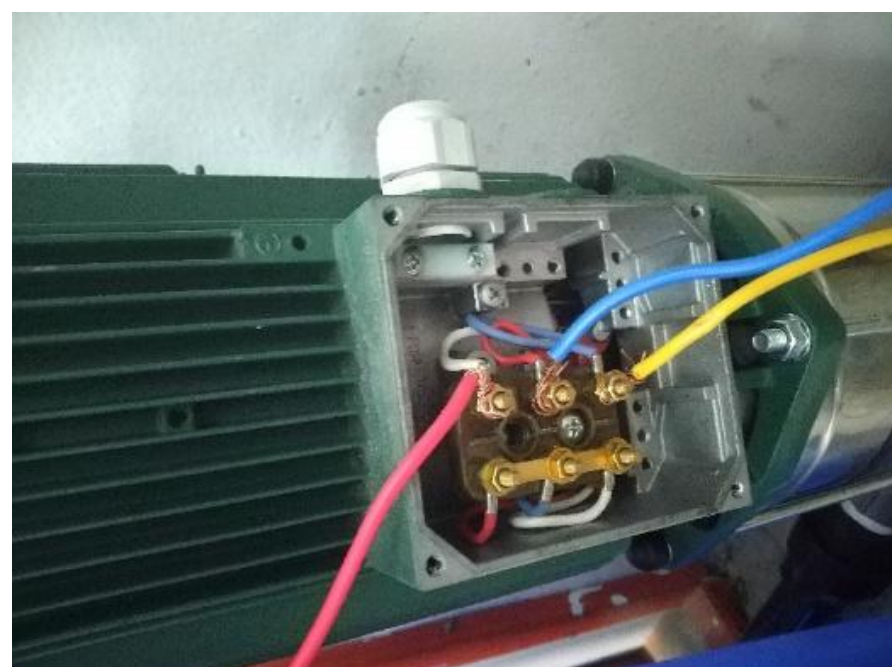

Fig. 5. The Star connection at the motor terminals. R,Y,B wires joined to the top three terminals and the bottom terminals are looped with copper bars.

It must be noted that in most cases in industry, the motor terminals are connected in delta $(\Delta)$ format where there are three $\varnothing$ wires joined to three terminals but the copper bars are joined vertically. Meaning the first top and first bottom terminal are joined then the second terminal is joined to the second bottom terminal and the third top terminal is connected to the third bottom terminal. Another starter called DOL (direct on line) is built for the $1 \mathrm{HP}$ pump and this is shown in at the bottom of Fig. 6, right, utilizing just one contactor. The choice of which motor starter to use is shown in Table 2 [16].

TABLE II. HP RANGES FOR VARIOUS STARTERS

\begin{tabular}{|c|c|}
\hline Induction Motor Starter & Motor loading, $\mathrm{X}$ \\
\hline Direct On Line (DOL) & $1 / 4 \mathrm{HP} \leqslant \mathrm{X} \leqslant 1 \frac{1 / 2 \mathrm{HP}}{} \leq \mathrm{X} \leqslant 3 \mathrm{HP}$ \\
\hline Star Delta & No lower or higher limita \\
\hline Autotran & \\
\hline VFD & \\
\hline & \\
\hline
\end{tabular}

Fig. 6. Top is the autotran circuit and bottom right is the DOL circuit 
The whole top of Fig, 6 is the autotran circuit. The DOL circuit consists of just one contactor. The pressure sensor will instruct it or send switching on signal to the coil (terminals A1 and A2) of the contactor. The advantage of using a contactor is that triggering a switch on with a push button using a finger could be too slow, thereby the arc generated as the motor draws energy can be quite significant and dangerous for the human operator as well as the motor. With a contactor, even if the push button is pressed slowly (or in this case the pressure sensor triggering slowly) is not a problem because the high current wires are joined very fast by the contactor's solenoid joined to the A1 and A2 terminals [14].

Another starter circuit is the Primary Resistance which has the same circuit as the autotran but is smoother during startup. So, it is used by very large motors that cannot withstand jerks. Then there is the VFD (variable frequency drive). The VFD provides a perfectly smooth increase in voltage but the price is not appropriate. In fact, there are many cases of factory or other systems owners using VFD and regretting later. For example, almost all oil palm mills in Sarawak use a $\$ 10,000$ VFD to run the conveyor which brings in the oil palm bunches to the boiler. Upon query of how a failure of the VFD is overcome, the answer was to purchase another unit of VFD as a spare. That is $\$ 20,000$ to run the conveyor motor! Comparatively very much cheaper speed reduction solutions is a gearbox, which is an old technology and is therefore perfected and much cheaper. Another induction motor speed reducer is a cyclovconverter. Cycloconverter is an old device that uses only diodes. And since diodes are the oldest electronic invented, it is cheap at just \$100-200 for a 25HP one. The way it works is for example the bottom of four sinusoids is cut off. Then the top of four sinusoids is cut off. Now the new AC waveform will be four times slower; providing four times slower speed for the induction motor. Cycloconverters are used to run trains and propellers of ocean-going ships (azimuth thrusters). It must be noted that these are super critical activities but yet, the perfectly controllable VFDs are not used. This is because the top design engineers know the price and reliability of VFD (a full computer) does not match such a critical activity. The autotran circuit used in this project cost only $\$ 126$. Fig. 7 is the autotran power circuit and Fig. 8 is the autotran control circuit [14].

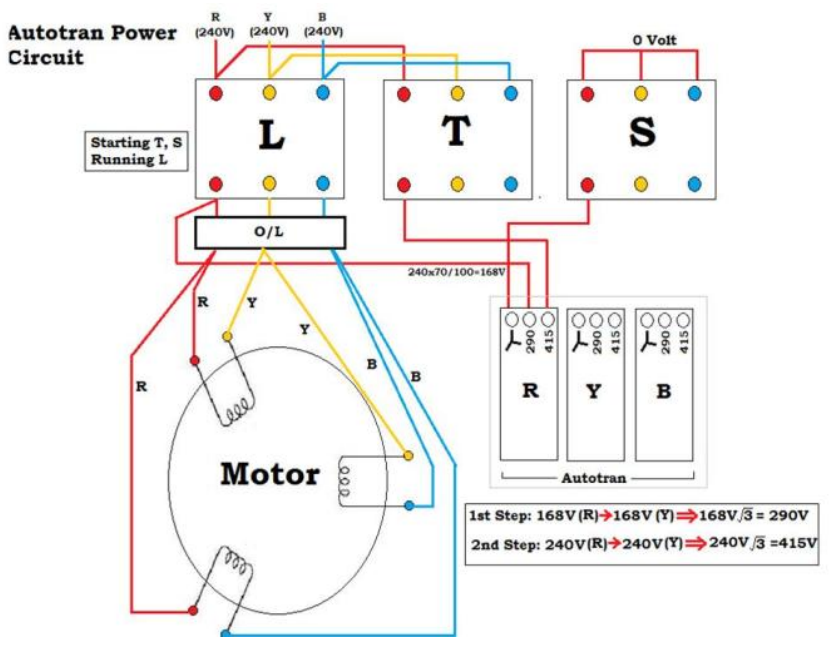

Fig. 7. The autotran power circuit

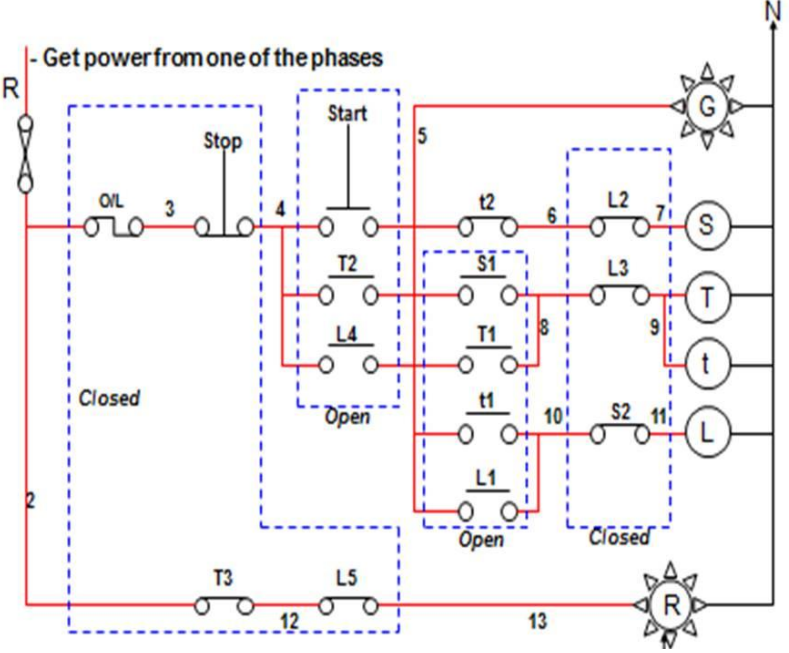

Fig. 8. The autotran control circuit

The next step is to bring the whole system to the village which is two hours away by car. At the site, temporary supply was connected and the system was energized but no water came up from the river. A hypothesis for the reason is that the $4 \mathrm{HP}$ pump was sucking air within the $120 \mathrm{~m}$ of $1 \frac{1}{2}$ " HDPE pipe and the air pressure will never be enough to pull the water over the $120 \mathrm{~m}$ horizontal and 9m vertical HDPE pipe. But it was a dry season and there was no water anywhere. On the next trip, a combustion engine pump as shown in Fig. 9 right bottom was purchased. Four rolls of garden hose of dimension $\emptyset=15 \mathrm{~mm}$, $3 \mathrm{~mm}$ thickness and 30m long was also purchased [15].

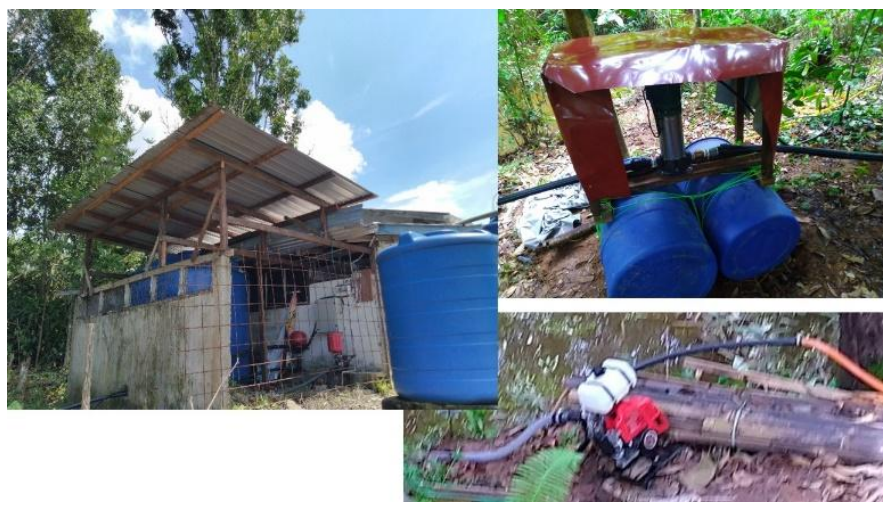

Fig. 9. Left is the pump house; right top is the 4 HP pump near the river and bottom right is the combustion engine pump. The two red pressure booster tanks are for the $1 \mathrm{HP}$ and $4 \mathrm{HP}$ tanks, the specification of which are in Table 3.

TABLE III. THE SPECS OF THE PRESSURE BOOSTER

\begin{tabular}{|c|c|}
\hline Rated Size & 12 Gallons \\
\hline Diameter x Height & $350 \mathrm{~mm} \mathrm{x} \mathrm{354mm}$ \\
\hline Connector & 1 " \\
\hline Maximum Pressure & 8 Bar \\
\hline Pre-Charge Pressure & 2 Bar \\
\hline Capacity & 24 Litre \\
\hline
\end{tabular}

They were joined with double male connectors (plastic) and hose clips. At the river side of the combustion engine pump was a heavy-duty steel reinforced plastic hose; or else this hose 
will just collapse due the sucking by the pump. It took some time before water came up to the Pump House. Eventually the problem was traced to one of the FYP (final year project) students over-tightening one of the many hose clips. With the water from the combustion engine pump, the $120 \mathrm{~m}$ of $1 \frac{1}{2}$ " HDPE pipe was filled with water. The 4 HP pump was energized but still no water came out [15].

Then a hypothesis was made that if the combustion engine pump can push up water from the river over $120 \mathrm{~m}$ horizontally and $9 \mathrm{~m}$ vertically, the $4 \mathrm{HP}$ pump will definitely be able to do the same thing. But the river may swell so a wooden platform was built and tied to two used chemical drums as shown in Fig. 10 top right.

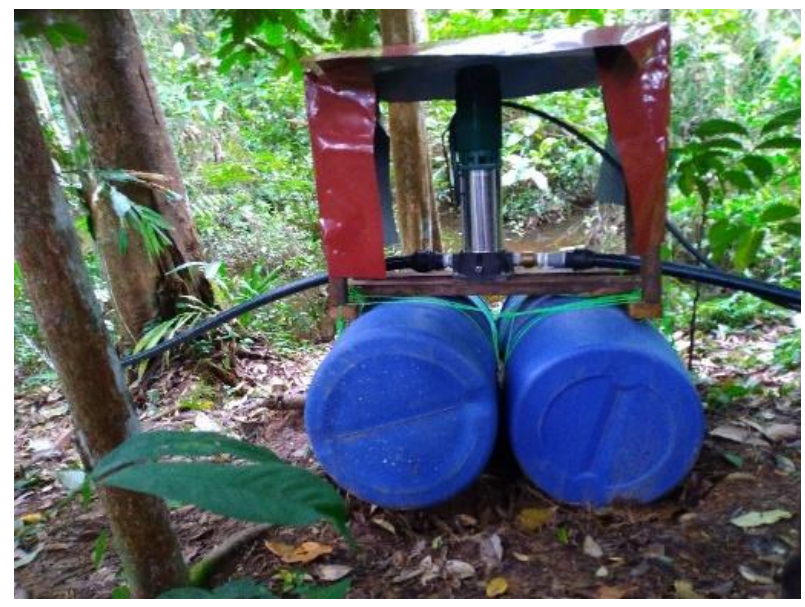

Fig. 10. The 4 HP pump is placed on a wooden structure which is tied to two used chemical drums as floats

The 4 HP pump was then fastened to the wooden platform. Despite this, no water came out. Then priming of the pump was done by placing an elbow at the output hole of the pump and pouring water with a mug to a hole at the impeller and opening and closing the stainless-steel nut at the bottom of the impeller. Only after one hour, a sudden gush of water came out. The 11/2" HDPE pipe was quickly reconnected and water quickly ended at the Pump House and was quickly connected to the inlet of the 9000L tank.

A study was made on the reason for the one hour to get the water to start coming out and it was discovered that it was due to an air-lock. At the incoming point of the 1/2" HDPE pipe, there is a bump as it was tied to a billian wood (Eusideroxylon Zwageri is the scientific name) driven to the deepest portion of the river. Billian wood is an especially hard wood which can last for hundreds of years even in water [16]. At the very end of the 1/2" HDPE pipe is a solid metal cylinder shaped netting to keep out vegetation and a one-way valve to keep water within the pipe and not flow back out to the river due to gravity. To solve the air-lock problem another two, used chemical drums were purchased and tied together with two ratchet ropes. A third ratchet rope was used to hold the incoming of the $1 \frac{1}{2}$ " HDPE pipe below the chemical drums as shown in Fig. 11. A learning here is that this author took almost an hour trying to do the attachment of the $1 \frac{1}{2}$ " HDPE pipe to the chemical drums in the water before giving up and bringing up the whole system to the river bank and doing it perfectly. The learning here is that humans cannot do work properly in non-terrestrial regions. Most work should be done in a terrestrial location and only little hook ups can be done in non-terrestrial regions. Non-terrestrial work includes underwater or in space.

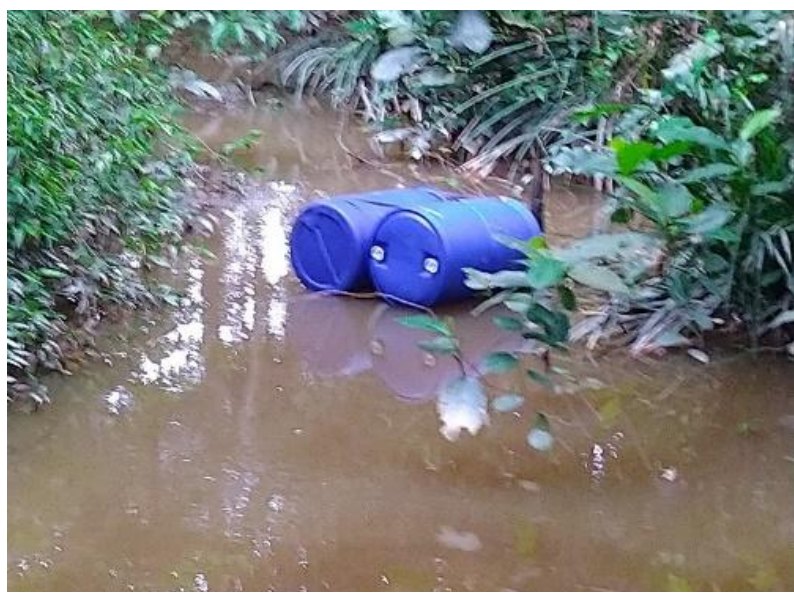

Fig. 11. The incoming $1 \frac{1}{2}$ “Ø $Ø$ HDPE incoming pipe is tied below the two blue drums float which are fastened together with truck ratchet ropes

The appropriate cable to be used must be determined according to the voltage drop calculation [17]:

Length of the cable $=120 \mathrm{~m}$, Voltage Supply $=415 \mathrm{~V}$ Power of the pump $=4 \mathrm{HP} ; 4 \mathrm{HP} \times 746=2984 \mathrm{~W}$

$$
\begin{gathered}
P=\sqrt{3} V I \cos \theta, \quad I=\frac{P}{\sqrt{3 V \cos \theta}}, \\
I=\frac{2984}{\sqrt{3(415)(0.8)}} 5.189 A=5.189 A \\
\text { Voltage Drop }=\frac{M V x I x L}{1000}
\end{gathered}
$$

Trying $1 \mathrm{~mm}^{2}$ cable:

$$
\begin{gathered}
\text { Voltage Drop }=\frac{38(5.189)(120)}{1000}=23.66 \mathrm{~V} \\
\frac{23.66}{415} \times 100=5.7 \%
\end{gathered}
$$

Trying $1.5 \mathrm{~mm}^{2}$ cable:

$$
\begin{gathered}
\text { Voltage Drop }=\frac{25(5.189)(120)}{1000}=15.57 \mathrm{~V} \\
\frac{15.57}{415} \times 100=3.75 \%
\end{gathered}
$$

According to IEE $17^{\text {th }}$ Edition, the voltage drop must not exceed $4 \%$ therefore $1.5 \mathrm{~mm}^{2}$ cable can be used. But considering the harsh environment the next bigger cable which is $2.5 \mathrm{~mm}^{2}$ was used [17].

The next many months was spent doing and redoing wiring to satisfy the Local Electrical Authority (LEA). The measurements using all the testing meters were also done. The testing was done to confirm the circuit is safe as shown in Table 4 and Table 5. 


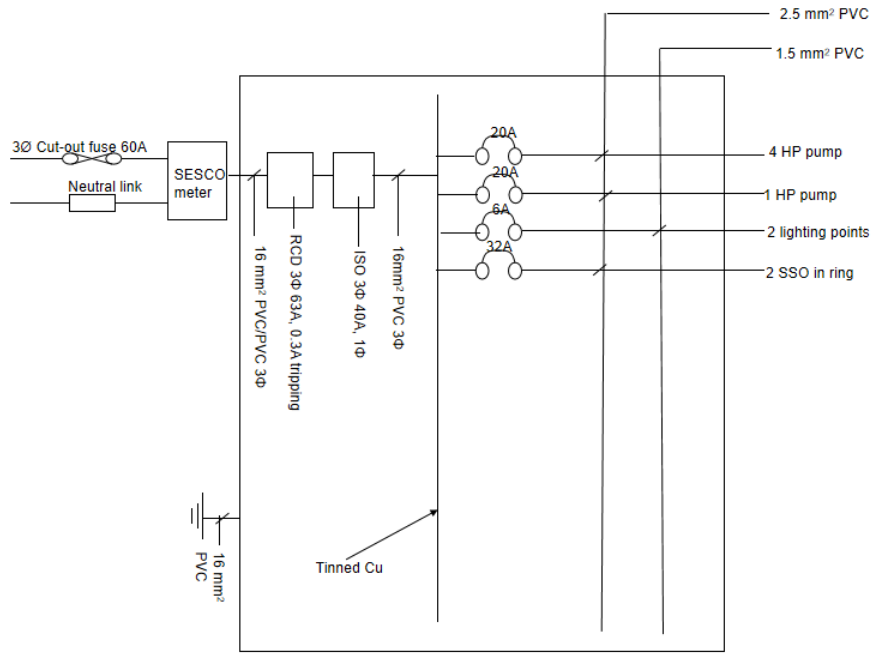

Fig. 12. The single line diagram of the wiring submitted to the LEA

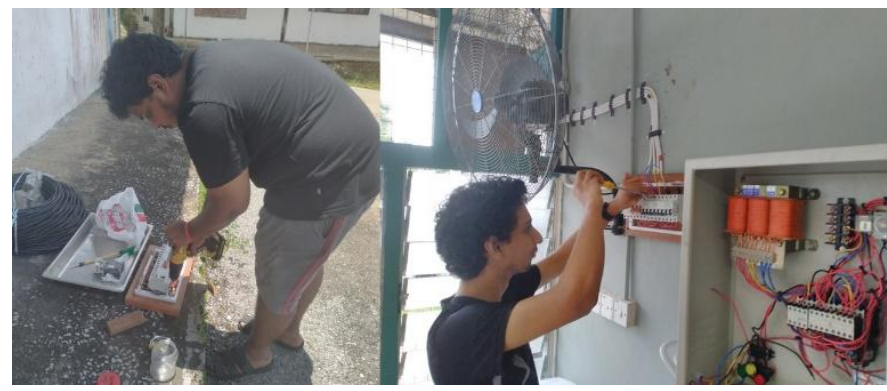

Fig. 13. Two of the co-authors at work on the project

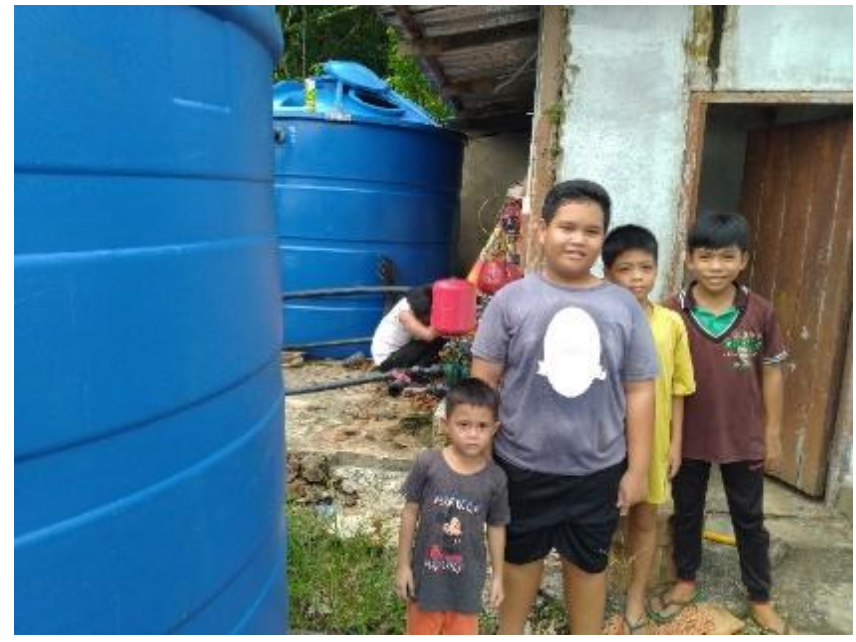

Fig. 14. The village children and one co-author in the background building the system
TABLE IV. THE ELECTRICAL TESTING DONE TO SUBMIT TO THE LEA Earth Resistance Test with Kyoritsu Model 4102A Earth Resistance of the Rod

65.2

\begin{tabular}{|c|c|}
\hline Voltage Drop Test at the motor terminals with Fluke 376 \\
\hline Motor Terminal & Voltage, $\mathrm{V}$ \\
\hline $\mathrm{RN}$ & $239.9 \mathrm{~V}$ \\
\hline $\mathrm{YN}$ & $240.2 \mathrm{~V}$ \\
\hline $\mathrm{BN}$ & $240.3 \mathrm{~V}$ \\
\hline
\end{tabular}

\begin{tabular}{|c|c|}
\hline \multicolumn{2}{|l|}{ The Insulation Test with Kyoritsu 3132A } \\
\hline Connection Probe & $\Omega$ \\
\hline RYBN-E \\
RYBN-N \\
RY \\
RB \\
YB & $\begin{array}{c}\text { IEE recommended } \\
\text { method to memorize }\end{array}$ \\
\hline RE & \\
\hline YE & $>1 \mathrm{M}$ \\
\hline BE & $>1 \mathrm{M}$ \\
\hline NE & $>1 \mathrm{M}$ \\
\hline RN & $>1 \mathrm{M}$ \\
\hline YN & $>1 \mathrm{M}$ \\
\hline BN & $>1 \mathrm{M}$ \\
\hline RY & $>1 \mathrm{M}$ \\
\hline RB & $>1 \mathrm{M}$ \\
\hline YB & $>1 \mathrm{M}$ \\
\hline
\end{tabular}

TABLE V. FURTHER ELECTRICAL TESTING DONE TO SUBMIT TO THE LEA

\begin{tabular}{|c|c|}
\hline \multicolumn{2}{|l|}{ Voltage Test from Service Line with Fluke 376} \\
\hline Incoming Voltage & Voltage, V \\
\hline R-N & 240.3 \\
\hline Y-N & 240.5 \\
\hline B-N & 240.2 \\
\hline R-Y & 414.9 \\
\hline R-B & 415.6 \\
\hline B-Y & 415.3 \\
\hline
\end{tabular}

\begin{tabular}{|l|c|}
\hline Phase Sequence Test Kyoritsu 8031 \\
\hline Phase Sequence Meter Connected to RYB & Result \\
\hline Turn Clockwise & $\checkmark$ \\
\hline Turn Anti Clockwise & $\mathrm{x}$ \\
\hline
\end{tabular}

\begin{tabular}{|l|c|}
\hline \multicolumn{2}{|l|}{ Earth Fault Loop Impedence Kyoritsu 4118A } \\
\hline Probed between L and E & $80 \Omega$ \\
\hline
\end{tabular}

RCD tester Kyoritsu Model 5402D

LEA requires taking three readings

1) NO TRIP (not tripped at $1 / 2$ rated $A$ )

2) Switched to TRIP and 0 degrees $(<200 \mathrm{~ms}$

3) TRIP and 180 degrees (<200ms) 
TABLE VI. TABLE 6: COST COMPARISON PER YEAR BEFORE AND AFTER THE WATER SUPPLY PROJECT

\begin{tabular}{|l|l|c|l|c|}
\hline & Before water supply project & USD & After water supply project & USD \\
\hline 1 & $\begin{array}{l}\text { Most villagers purchase a water } \\
\text { dispenser and load it with a big } \\
\text { bottle of water. Alternatively they } \\
\text { may purchasae standard 1.5L } \\
\text { bottles of water. Estimate cost is } \\
\text { MYR50 per month X 12 X 38 }\end{array}$ & 495 & $\begin{array}{l}\text { With water supplied, only electric bill } \\
\text { need to be paid but the Local } \\
\text { Electric Authority (LEA) said it will } \\
\text { be waived for this particular project. } \\
\text { Spare parts estimated at } \\
\text { MYR100/year }\end{array}$ & 25 \\
\hline 2 & $\begin{array}{l}\text { For bathing, most villagers use a } \\
\text { big blue plastic tanks to harvest } \\
\text { water from rooftops. But there is } \\
\text { no rain during the dry seasons of } \\
\text { June, July and August. Then } \\
\text { villagers have to go to the river to } \\
\text { bath of spend some money to } \\
\text { clean themselves. Estimate cost }= \\
\text { MYR30 per home X 38 homes X 3 }\end{array}$ & 855 & Free water to bath with. & 0 \\
\hline 3 & $\begin{array}{l}\text { All villagers use gas stoves } \\
\text { MYR28 X12 X 38 homes =12768. } \\
\text { Plus an estimate of MYR500 for } \\
\text { stove repair/replacement per year } \\
\text { for all 38 homes }\end{array}$ & 3317 & $\begin{array}{l}\text { Bring design of stove that burn dried } \\
\text { vegetation from Kerala, India which } \\
\text { has no lagging smoke smell in the } \\
\text { kitchen. One time cost of } \\
\text { MYR1000 and replicating cost borne }\end{array}$ & 250 \\
\hline & 4667 & 275 \\
\hline
\end{tabular}

\section{CONCLUSION}

This research project which was valued at $\$ 11,250$ provided the main need for the 180 people of Kampung Abit village. Most vendors will charge multiple hundreds of percent of that value to achieve that level of success.

Projects such as these should be a focus of university researchers in Malaysia since most high-end research in the latest electrical and electronic developments require the very latest high-end laboratories. It was noticed that some researchers in these countries purchase out-of-date equipment from more advanced countries. Being even a few years old will not enable them cannot carry out the leading-edge research. Fabs and all the required measuring equipment can run to 100 s of million dollars [18]. Also, collaborations must be made with multiple researchers spanning many companies as sub vendors. Therefore, the best value for researchers in Malaysia is to use or modify technologies to alleviate the suffering of the poor who do not have the basic requirements to live decent lives. Correspondingly, it is good for university researchers in more advanced countries which make the latest electronics and data management software to work with such companies to develop the leading-edge technologies in those fields. Researchers of those countries do not have much opportunities to do research such as this because the materialistically poorer people are harder to find.

It is also the best way for FYP to put to practice their four years of engineering training. The engineering solutions not only alleviate the suffering of the poor but also to bring about confidence among the villagers who need to be shown a way out of dejection which tends to lead to abuse of alcohol and so forth. The whole country can benefit from the output of farms enabled with the availability of water and the output of the metal works get sold in the market. The dejection and poverty trap of the poor, if not addressed can also lead to revolts which will affect the whole country. The Homestay business will enhance the quality of the richer youths of the city as well as much needed income for the poorer villagers. The ROI for the country with research such as this is much higher than investing in large multinationals who tend even to avoid paying taxes.

Within this village, the impact of this project will go a long way in alleviating many of the hardships faced by the villagers in the absence of piped water facilities to their homes. They are now able to enjoy clean, hygienic, as well as uninterrupted water supply. Apart from providing better health and sanitation, the facility now frees them from the time and effort they would have to spend to go down to the river for bathing, washing and collecting water for their homes. The time saved can now be diverted to other productive efforts like using it to tend to their crops and home implements, and other activities to improve their economic livelihood. During dry spells, the water can be channeled to water their vegetables and crops. The economic impact of this project on the livelihood of the villagers is large and some of these are listed in Table 6 . The optimum solution of this project was to use a 4 HP $3 \varnothing$ induction motor pump, placed near the river bank and pump it to $120 \mathrm{~m}$ horizontally and $9 \mathrm{~m}$ vertically to a $900 \mathrm{~L}$ holding tank. An autotran starter circuit and wiring as required to satisfy the LEA (local electrical authority) was done. The holding tank has a float sensor and pressure sensor to stop the pump when the tank is full. The next steps of increasing the economic income of the village can now be worked upon which is vegetable farming, metal foundry, wood burning stoves and Homestay business.

In human history, many of the technologies to acquire water have been well documented but are not well modified to suit the particular climatic or social conditions of each group of populations. This is why today 600 million people on earth are living in extreme poverty [19].

\section{ACKNOWLEDGEMENT}

This work was supported by the University Research Grant, of University College of Technology Sarawak (UCTS), Sarawak, Malaysia under a S11,250 grant.

\section{REFERENCES}

[1] Furuoka, F. (2014). Economic Development in Sarawak, Malaysia: An overview.

[2] Berma, M. (2003). Towards the national vision policy: Review of the New Economic Policy and New Development Policy among the bumiputera communities in Sarawak. The Bumiputera Policy: Dynamics and Dilemma.

[3] Huu, J. H. W., AbdLatif, I., \& Nasir, A. M. (1999). Lead-lag relationship between housing and gross domestic product in Sarawak. In Paper presented at The International Real Estate Society Conference (Vol. 26, No. 30).

[4] Rabbani, G., Rahman, S. H., \& Faulkner, L. (2013). Impacts of climatic hazards on the small wetland ecosystems (ponds): evidence from some selected areas of coastal Bangladesh. Sustainability, 5(4), 1510-1521.

[5] Curry, E. (2010). Water scarcity and the recognition of the human right to safe freshwater. Nw. UJ Int'1 Hum. Rts., 9, 103.

[6] Prakash, A. V., \& KUMAR, L. V. (2005). Water Quality Study on Rivers in Sarawak (Doctoral dissertation, Bachelor's Thesis, University Malaysia Sarawak, Samarahan, Malaysia, 2005.[Google Scholar]).

[7] Ngah, I., Preston, D., \& Asman, N. (2010, June). Current Planning Priorities in Rural Villages in Malaysia Learning from The New Malaysian Village Action Plans. In ISDA 2010 (pp. 9-p). Cirad-InraSupAgro.

[8] Jomo, K. S., \& Sundaram, J. K. (2004). The new economic policy and interethnic relations in Malaysia. 
[9] Ravallion, M. (2020). Ethnic inequality and poverty in Malaysia since May 1969. Part 2: Poverty. World Development, 134, 105039.

[10] Kong, Y. L., Anis-Syakira, J., Fun, W. H., Balqis-Ali, N. Z., Shakirah, M. S., \& Sararaks, S. (2020). Socio-Economic Factors Related to Drinking Water Source and Sanitation in Malaysia. International Journal of Environmental Research and Public Health, 17(21), 7933.

[11] Rahmat, S. N., Adnan, M. S., \& Ayob, S. (2017). Water protection: Capturing the benefits and limitations of rainwater harvesting and groundwater as alternative sources.

[12] Puah, C. H., Jong, M. C., Ayob, N., \& Ismail, S. (2018). The impact of tourism on the local economy in Malaysia. International Journal of Business and Management, 13(12), 151-157.

[13] Rashid, M. F., Ngah, I., \& Misnan, S. H. (2019, November). Revitalizing Rural Areas in Malaysia: A Framework for Economic Revitalization. In IOP Conference Series: Earth and Environmental Science (Vol. 385, No. 1, p. 012004). IOP Publishing.

[14] Karunakaran, P. (2018). Electrical Power Simplified. AuthorHouse.

[15] Karunakaran, Prashobh; Osman, M. Shahril; Greve, Dylan; Jesse, Timothy; V. Karuppanna; Sung, Chee Cheng; Lee, Man Djun; Chioma,
Augustine; Wong, Chee Chung. (2020). Water Supply for a Village in Sarawak, Malaysia. STAGE 2020: International conference on Sustainable Technology Applications for Green Energy solutions. NSS College of Engineering. Palakkad, India, 18/7/2020.

[16] Purba, J. H., Sasmita, N., Komara, L. L., \& Nesimnasi, N. (2019). Comparison of seed dormancy breaking of Eusideroxylon zwageri from Bali and Kalimantan soaked with sodium nitrophenolate growth regulator. Nusantara Bioscience, 11(2).

[17] Karunakaran P. Electrical Power simplified. (2020/4/29), Amazon ASIN: B087XBNXV3. ISBN: 978-1-5462-6246-6 (sc), 978-1-5462-6247-3(e). 271 pages.

[18] Keith, C., Chen, A., Albalak, H., \& Anvar, M. (2020, August). Output Improvement in High Volume Memory Fabs by Reducing Recipe Qualifications. In 2020 31st Annual SEMI Advanced Semiconductor Manufacturing Conference (ASMC) (pp. 1-3). IEEE.

[19] Şensoy, S., Coşkun, M., Türkoğlu, N., \& Çiçek, İ. (2018). Future Earth and Expected Mega Changes. Global Change and Future Earth: The Geoscience Perspective, 3, 15. 